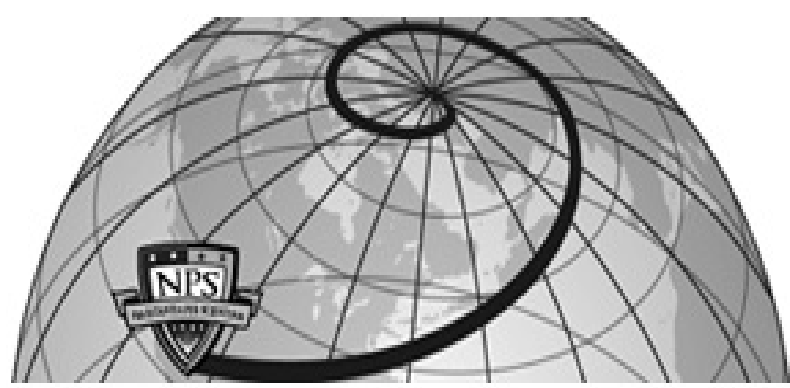

Calhoun: The NPS Institutional Archive DSpace Repository

Dumping and Subsidy Cases at the ITC: Voting Discretion and Commissioner Attributes

Brook, Douglas A.

The International Trade Journal, Volume XIX, No. 4, Winter 20065, DOI: 10.1080/08853900500290731 https://hdl.handle.net/10945/44478

This publication is a work of the U.S. Government as defined in Title 17, United States Code, Section 101. Copyright protection is not available for this work in the United States.

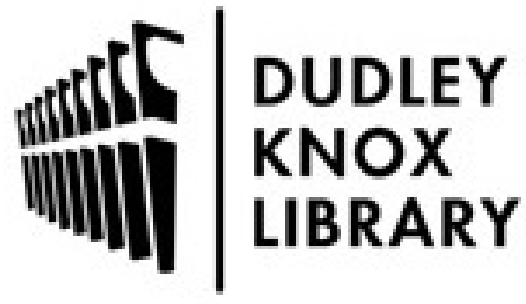

http://www.nps.edu/library
Calhoun is the Naval Postgraduate School's public access digital repository for research materials and institutional publications created by the NPS community. Calhoun is named for Professor of Mathematics Guy K. Calhoun, NPS's first appointed -- and published -- scholarly author.

Dudley Knox Library / Naval Postgraduate School 411 Dyer Road / 1 University Circle Monterey, California USA 93943 


\section{DUMPING AND SUBSIDY CASES AT THE ITC: Voting Discretion and Commissioner Attributes}

\section{Douglas A. Brook}

In antidumping and countervailing duty cases, why do commissioners of the International Trade Commission vote as they do? Commissioners are presented with the same petitions, listen to the same oral arguments, have access to the same economic data, and operate under the same trade laws. Yet there is variability in voting behavior. Political economy models have left an incomplete understanding of ITC voting and recent literature suggests there may be attributes of the commissioners that explain their voting behavior. This study of votes on antidumping and countervailing duty cases between 1992 and 1999 looks at five such attributes: political party, party of the appointing president, prior employment on Capitol Hill, profession as lawyers, and prior employment in business and labor organizations. Applying a statistical analysis reveals that, of these five variables, only prior affiliation with business and labor organizations and political party appear related to ITC Commissioners'voting patterns.

Douglas A. Brook is Professor of Public Policy at the School of Business and Public Policy, Naval Postgraduate School, Monterey, California.

THE INTERNATIONAL TRADE JOURNAL, Volume XIX, No. 4, Winter 2005 309 ISSN: 0885-3908 print/1521-0545 online. DOI: 10.1080/08853900500290731 


\section{INTRODUCTION}

In deciding antidumping and countervailing duty cases, why do the commissioners of the International Trade Commission vote as they do? Scholars have studied the ITC seeking to understand the determinants for decision-making on trade cases. Political economists have sought to understand the extent to which commissioners' votes are based on economic analysis and statutory criteria. These explanations often have left a sense of incomplete understanding. Others, therefore, have assessed the exercise of discretion by commissioners, and still others have examined the extent to which political considerations appear to enter into Commission determinations. Many have now come to believe that the exercise of discretion can be as important as statutory economic factors in ITC decisions in antidumping and countervailing cases.

In deciding on antidumping (AD) and countervailing duty (CVD) cases, ITC commissioners must make determinations on whether dumping and subsidies have resulted in injury, or the threat of injury, to the petitioners. They do so by applying certain statutory criteria. Yet, individual commissioners with the same data, hearing the same testimony, and supposedly applying the same set of statutory economic evaluative criteria, often reach different conclusions. What explains these apparent acts of discretion on the part of individual commissioners? This article attempts to fill some of the gap in our understanding of this question by examining the votes of the ITC commissioners between 1992 and 1999.

\section{LITERATURE REVIEW}

The scholarly literature on ITC decision-making indicates that commissioners operate within a range of discretion on antidumping cases, albeit within statutory boundaries. This ex- 
ercise of discretion is explained within two broad categories of analysis: economic determinism and political economy explanations. However, even many of the economic analyses concede the possible presence of political considerations. As Blonigan and Prusa observed, “... no other trade instrument has AD's unique combination of political and economic manipulability, incentives, and intrigue." ${ }^{1}$ Similarly, DeVault observed that, in principle, ITC decisions are based entirely on statutory considerations, but "(I)n practice, ITC decisions may be influenced by other factors, including the idiosyncracies of ITC commissioners ... or political pressure from Congress and the President." 2

\section{Economic Bases for Decisions}

The Commission is directed by law to consider certain statutory criteria in making its decisions, such as changes in prices, employment, capacity utilization, profitability, and market share. But commissioners exercise discretion in the weight and importance that they give to each. Kaplan ${ }^{3}$ found that commissioners exercise discretion in conducting their reviews of economic data and "trends analysis" is frequently used by some commissioners in determining whether imports are a cause of injury. Baldwin and Steagall ${ }^{4}$ observed four other commonly used variables in $\mathrm{AD}$ cases: the ratio of total imports to consumption, changes in capacity, the direction of change in dumped and subsidized

\footnotetext{
${ }^{1}$ Bruce A. Blonigan and Thomas J. Prusa, "Antidumping," NBER Working Paper Series, (Cambridge, National Bureau of Economic Research, July, 2001): 1.

${ }^{2}$ James M. DeVault, Congressional Dominance and the International Trade Commission," Public Choice, vol. 110 (2002): 2.

${ }^{3}$ Seth Kaplan, "Injury and Causation in USITC Antidumping Determinations: Five Recent Approaches," in P. K. M. Tharakan (ed.), Policy Implications of Antidumping Measures, (Amsterdam: North Holland, 1991): 143-173.

${ }^{4}$ Robert E. Baldwin and Jeffrey W. Steagall, "An Analysis of ITC Decisions in Antidumping, Countervailing Duty and Safeguard Cases," Weltwirtschaftliches Archives, vol. 130 (1994): 290-308.
} 
imports, and whether the product had been the subject of a similar previous investigation. They also found that individual commissioners varied in the choice of economic variables used to reach a determination. Anderson, ${ }^{5}$ on the other hand, found that statutory considerations were stronger explanations of ITC decisions than discretionary models. The discretionary models Anderson considered were the "adding machine model" wherein the ITC seeks to maximize the re-election chances of incumbent lawmakers, and the "interest group" model that considers an industry's influence with members of the relevant Congressional oversight committees. These are compared with two economic models: the "comparative effects" model that considers the actual economic effects of dumping, and the "trends" model that focus on changes in industry conditions over time.

Liebman's ${ }^{6}$ analysis of ITC sunset reviews of AD cases found that commissioners adhere to the prescribed legal framework in deciding their votes. However, he also found evidence of favorable treatment towards industries located in "voting districts" (sic) of Senate oversight committee members.

Sabray $^{7}$ examined the decision to file antidumping petitions and finds industry concentration, capacity utilization, and the import penetration ratio to be significant factors in the decision to file. While not directly considering the potential political strength of concentrated industries, Sabray, nevertheless found that highly concentrated industries are more likely to secure protection.

\footnotetext{
${ }^{5}$ Keith B. Anderson, "Agency Discretion or Statutory Direction: Decision Making at the U. S. International Trade Commission," Journal of Law and Economics, vol. 36 (October, 1993): 915-935.

${ }^{6}$ Benjamin H. Liebman, "ITC Voting Behavior on Sunset Reviews, University of Oregon Department of Economics Working Paper (August, 2001).

${ }^{7}$ Faten Sabray, "An Analysis of the Decision to File, The Dumping Estimates, and The Outcome of Antidumping Petitions," The International Trade Journal, vol. 14, no. 2 (Summer 2000): 109-145.
} 


\section{Political and Political Economy Models}

Moore $^{8}$ found that ITC decisions were consistent with the standards set forth in trade legislation. However, Moore also found that petitions involving constituents of members of the Senate trade subcommittee were treated more favorably than others. Thus, the congressional oversight process is seen as a possible avenue of influence for "rent seeking special interests." 9 But no corresponding suggestion of influence was found for members of the House oversight committee. In Moore's study of ITC decisions for the period 1980-1986, Republicans were found to be more protectionist than Democrats, yet the two commissioners least likely to vote for protection were a Republican (Brunsdale) and a Democrat (Liebeler).

Brook $^{10}$ suggested evidence of party cohesion in ITC votes on the 1992 steel cases. In this case, Democrat commissioners supported protection more than Republican commissioners by a two-to-one margin. Moore, however, did not view partisan affiliation as the decisive factor in voting on the ITC. Instead he suggested that future studies might look at other aspects of a commissioner's background, including regional biases and ideological affiliations. He concluded that the composition of the ITC is extremely important to its decisions.

Baldwin and Steagall ${ }^{11}$ presented a political economy model for the selection of ITC commissioners wherein presidents and

\footnotetext{
${ }^{8}$ Michael O. Moore, "Rules or Politics? An Empirical Analysis of ITC Antidumping Decisions," Economic Inquiry, vol. 30 (July, 1992): 449-466.

${ }^{9}$ Michael O. Moore, "Rules or Politics? An Empirical Analysis of ITC Antidumping Decisions," Economic Inquiry, vol. 30 (July, 1992): 450.

${ }^{10}$ Douglas A. Brook, "Trade Policy Strategies and Enforcement Choices: An Examination of the 1992 Steel Antidumping Cases," International Trade Journal, vol. 17 , no. 1 (Spring 2003): 97.

${ }^{11}$ Robert E. Baldwin and Jeffrey W. Steagall, "An Analysis of ITC Decisions in Antidumping, Countervailing Duty and Safeguard Cases," Weltwirtschaftliches Archives, vol. 130 (1994): 290-308.
} 
senators seek to maximize the political return for appointment and confirmation of ITC commissioners. Congressional oversight of the Commission is exercised through the confirmation and appropriations processes. Commissioners themselves may act in a manner to enhance their own future career interests. To Baldwin and Steagall this analysis "... suggests that political economy factors are likely to affect ITC decisions, mainly through the role they play in determining the type of person nominated and confirmed." Baldwin and Steagall also argued that the foreign policy interests of the White House and the constituency-based interest of senators result in a situation where "(A) president is unlikely to nominate individuals with highly protectionist views, while the Senate is unlikely to confirm those with strong free trade views." 12

Baldwin and Moore ${ }^{13}$ argued that Congress exercises considerable influence over implementation of trade laws through four means: changing the laws, changing the administering agencies, changing the administrative rules and regulations, and changing interpretation of the rules and regulations. The result, they concluded, is that the actions of the Department of Commerce tend to favor domestic companies over foreign entities.

Hansen and Prusa ${ }^{14}$ found that ITC decisions are influenced by both economics and politics. On the political side, they determined that antidumping petitioners with facilities in the states

\footnotetext{
${ }^{12}$ Robert E. Baldwin and Jeffrey W. Steagall, "An Analysis of ITC Decisions in Antidumping, Countervailing Duty and Safeguard Cases," Weltwirtschaftliches Archives, vol. 130 (1994): 294.

${ }^{13}$ Robert E. Baldwin and Michael O. Moore, "Political Aspects of the Administration of the Trade Remedy Laws," in Richard Boltuck and Robert E. Litan (eds.), Down in the Dumps: Administration of the Unfair Trade Laws, (Washington: Brookings, 1991), 253-280.

${ }^{14}$ Wendy L. Hansen and Thomas J. Prusa, "The Economics and Politics of Trade Policy: An Empirical Analysis of ITC Decision Making," Review of International Economics, vol. 5 (1997): 230-245.
} 
and districts of senators and representatives on the committees with oversight of the ITC have greater success. They also found that the likelihood of receiving protection from the ITC is related to an industry's PAC (political action committee) contributions to senators and representatives on oversight committees. Congressional influence, and by inference, industry political influence on the ITC, is exercised through the congressional oversight processes. (They control for steel because steel's successes may also relate to to its frequent filer status; i.e., the experience factor.)

Hansen's ${ }^{15}$ political economy model of trade policy considered both the "demand side" (industries seeking protection) and the "supply side" (ITC grants of protection). In this model, both economic and political considerations are at work. Hansen identified two theoretical foundations. "Capture" theory posits a competition among interests to lobby and influence legislators and regulators. Regulators or politicians grant regulation so as to maximize their political support. "Congressional dominance" theory, on the other hand, suggests that Congress controls the bureaucracy and regulators through oversight and appropriations. This model suggests that interests seeking to influence the regulators do so by directing their influence toward members of Congress with power over the bureaucracy. Hansen found some support for the congressional dominance model.

Blonigan and Prusa point out that " $(\mathrm{G})$ etting the 'right' person on the Commission clearly changes outcomes. No formal study has been done, however, on relating the previous backgrounds of the commissioners to their voting records." ${ }^{16}$ Baldwin, however, examined the backgrounds of commissioners to

\footnotetext{
${ }^{15}$ Wendy L. Hansen, "The International Trade Commission and the Politics of Protectionism," The American Political Science Review, vol. 84, no. 1 (March, 1990): 21-46.

${ }^{16}$ Bruce A. Blonigan and Thomas J. Prusa, "Antidumping," NBER Working Paper Series, (Cambridge, National Bureau of Economic Research, July, 2001): 1.
} 
find evidence of the relative power of the executive and legislative branches in the selection of commissioners. Baldwin concluded that commissioners from academia and the executive branch were appointed with greater frequency when the president dominated the appointments process, and that appointments of commissioners with private sector or legislative branch experience occured when Congress dominated the appointments process. ${ }^{17}$

\section{RESEARCH DESIGN}

It would be reasonable to expect Commissioners hearing the same arguments and applying the same trade laws would reach similar decisions on AD and CVD cases. However, there is evidence of variability in the votes cast by ITC commissioners. The literature suggests that some characteristics of the commissioners could be related to the votes they cast. This study examines certain aspects of the political and professional backgrounds of commissioners who served between 1992 and 1999, first, to verify there is variance between commissioners' votes and second, to determine whether these voting differences relate to certain attributes of the commissioners:

1) party affiliation,

2) party of the appointing president,

3) prior employment as Congressional staff members,

4) prior employment in business and labor organizations, and

5) profession as lawyers.

Simple statistical tests are applied to votes on antidumping and countervailing duty cases between 1992 and 1999 .

${ }^{17}$ R. E. Baldwin, The Political Economy of U. S. Import Policy, (Cambridge: MIT Press, 1985): 96-97. 


\section{The Votes}

Preliminary and final votes on all (non-steel) antidumping and countervailing duty cases between 1992 and 1999 are analyzed. Preliminary votes take place upon receipt of petitions and the initial determinations of dumping or subsidies by the Department of Commerce. An affirmative preliminary vote means that there is sufficient indication of the presence of dumping or subsidies and the possibility of injury for the ITC to proceed with a formal investigation and injury determination. An affirmative final vote is a determination that injury, or the threat of injury is present and antidumping or countervailing duties should be imposed. The votes were on petitions involving a wide variety of industries and products, such as softwood lumber, portable seismographs, salmon, Portland cement, electric typewriters, paper clips, phthalic anhydride, pencils, pasta, semiconductors, and even cookies from Denmark. (Consistent with Hansen and Prusa, this study excludes the massive 1992 set of steel antidumping cases.)

The votes selected for analysis cover the eight-year period between 1992 and 1999, inclusive. This study looks at votes on approximately 25 preliminary and 29 final CVD cases, and on approximately 132 preliminary and 136 final AD cases. Eleven individual commissioners cast a total of 710 preliminary and 728 final antidumping votes, and 127 preliminary and 136 final countervailing duty votes. Summaries of these votes appear in Appendix I.

\section{The Commissioners}

These votes were cast by a total of 11 different commissioners. Members of the International Trade Commission are appointed by the President with the advice and consent of the Senate. Commissioners are appointed to 9-year non-renewable terms. 
No more than three commissioners may be from the same political party. Although political independents have been appointed to the Commission, all of the commissioners during this period of study were identified Democrats (six) or Republicans (five). Six were appointed by Republican presidents (Reagan and Bush) and five were appointed by a Democratic president (Clinton). Appendix II indicates data about the profession and prior employment of the commissioners. Six are lawyers, six have prior professional experience as staff members on Capitol Hill, and four have prior employment in business and labor organizations.

\section{Research Question}

This study seeks to determine whether significant differences occur between commissioners with or without certain attributes. The following specific attributes were considered:

- Political Party. Moore observed that Republican commissioners tended to favor protection more than Democratic commissioners during the period $1980-86 .{ }^{18}$ Brook observed party cleavage in the opposite direction. ${ }^{19}$ DeVault found no obvious correlation between protectionist voting and party. ${ }^{20}$ Baldwin found a correlation between party and votes in three periods between 1949 and $1983 .^{21}$ Does a distinction by party hold for the 1992-1999 period?

\footnotetext{
${ }^{18}$ Michael O. Moore, "Rules or Politics? An Empirical Analysis of ITC Antidumping Decisions," Economic Inquiry, vol. 30 (July, 1992): 464.

${ }^{19}$ Douglas A. Brook, "Trade Policy Strategies and Enforcement Choices: An Examination of the 1992 Steel Antidumping Cases," International Trade Journal, vol. 17 , no. 1 (Spring 2003): 97.

${ }^{20}$ James M. DeVault, Congressional Dominance and the International Trade Commission," Public Choice, vol. 110 (2002): 10.

${ }^{21}$ R. E. Baldwin, The Political Economy of U. S. Import Policy, (Cambridge: MIT Press, 1985): 90-92.
} 
Do Republican and Democratic commissioners vote differently, or is it possible that there is no difference?

- Party of the Appointing President. There could be some relationship between ITC votes and the party of the president who appointed the commissioners. There is an important distinction between consideration of the party of the appointing president and consideration of the party of the commissioners. Even though the commission must be bipartisan, presidents have great leeway to find and appoint members of each party who are most aligned with the trade policies of the Administration. Baldwin, however, found no correlation between between the party of the appointing President and the votes of his appointees of the opposite party. ${ }^{22}$ During the period under study, it might be argued that the political imperatives of a Democratic president (strong labor constituencies) would lead to more protectionist appointments than Republican presidents (philosophical free traders). Is there a difference between votes cast by commissioners appointed by a Democratic president and commissioners appointed by a Republican president, or is it possible that there is no difference?

- Lawyers. The duties of the ITC are quasi-judicial. Decisions of the Commission are supposed to be based on the application of statutory criteria. Some of the studies cited above indicate that statutory guidelines are, in fact, observed. One could expect therefore that lawyers on the Commission might have a more technical and legalistic approach to deciding how to vote; one that is less influenced by political considerations or personal experiences.

${ }^{22}$ R. E. Baldwin, The Political Economy of U. S. Import Policy, (Cambridge: MIT Press, 1985): 93. 
If so, the votes of lawyers might be expected to be similar and to differ from the votes of non-lawyers. Lawyers' votes can thus also serve as a sort of proxy for statute-based decision-making at the ITC. Do lawyers on the ITC vote differently than non-lawyers, or is it possible that there is no difference?

- Business and Labor. Similarly, business organizations and labor groups that invoke the antidumping laws might try to influence voting behavior through appointment of sympathetic members to the Commission. Unlike many public other policy areas, business and labor petitioners often are on the same side in trade cases, both engaged in trying to protect their industry and its jobs. ${ }^{23}$ Thus, Commissioners with prior experience in business or in labor organizations might be more sympathetic to the business and labor petitioners that filed the cases. Do commissioners with employment backgrounds in business and labor vote differently than those without such employment history, or is it possible that there is no difference?

- Congressional Staff. Liebman and others have suggested some relationship between favorable votes on antidumping petitions and the interests of members of Congress, particularly members of congressional oversight committees. Congressional dominance theory would suggest that Members of Congress exercise influence over ITC decisions through the selection of politically aligned commissioners, especially through the appointment of former members of their staffs. A majority of the commissioners in 1992-1999 had previous experience as Capitol Hill staff members, including some with service on the staffs of the Senate

${ }^{23}$ See, for example, Douglas A. Brook, "Meta-Strategic Lobbying," Business and Politics, vol. 7, issue 1 (2005): Article 4. 
Finance Committee and the House Ways and Means Trade Subcommittee. Do commissioners who were previously employed on Congressional staffs vote differently from commissioners without such previous employment, or is it possible that there is no difference?

\section{METHODOLOGY}

To verify that variability exists in commissioners' votes, the mean, standard deviation, and coefficient of variation were calculated for the affirmative vote percentages for each commissioner in preliminary and final antidumping and countervailing duty cases. Second, to determine whether voting behavior varies by commissioner attributes, two-sample $t$-tests and exact Wilcoxon rank sum tests were conducted. Both tests were used because of the small sample size.

While the two-sample $t$-test for equality of means is robust to non-normality for large samples, it is also an appropriate test for small samples if the underlying distributions are normal. Shapiro-Wilk tests for normality indicate that, except for final countervailing duty votes, the average percentage affirmative vote measures are normally distributed. In addition, results for the Kolmogorov-Smirov and Cramer-von Mises tests for normality indicate that all four of the affirmative vote measures are normally distributed. Separating the data by the classification variables (attributes of the commissioners) and testing for normality would yield stronger assurance, but this was not feasible given the even smaller sample sizes that would result. Consequently, though $t$-tests were performed (after testing for equality of variances and selecting the appropriate method for calculating $t$ ) a non-parametric test (the exact Wilcoxon rank sum test) was also included in the analysis so that the more powerful results of the $t$-tests would be supported by a comparable method that does not rely on the assumption of normality. 


\section{ANALYSIS}

The percentage of affirmative votes by each of the eleven commissioners on preliminary and final antidumping and countervailing duty petitions is shown in Table I. There is variability between commissioners on both preliminary and final votes, with the greatest coefficient of variation occurring in the votes on final determinations (.33 for final countervailing duty determinations and .27 for final antidumping votes). Further illustrating variability, the affirmative vote percentages on preliminary CVD cases range from .50 (Askey) to .87 (Bragg); on final CVD cases the range is .20 (Askey) to .80 (Koplan). For preliminary AD cases the affirmative vote percentages range from .63 (Askey) to .92 (Newquist); on final AD cases the range is .29 (Askey) to .71 (Koplan).

Table I

Percent Affirmative Vote, 1992-1999

\begin{tabular}{|c|c|c|c|c|}
\hline \multirow[b]{2}{*}{ Commissioner } & \multicolumn{2}{|c|}{ Countervailing Duty } & \multicolumn{2}{|c|}{ Antidumping } \\
\hline & Preliminary & Final & Preliminary & Final \\
\hline Brunsdale & .71 & .25 & .73 & .35 \\
\hline Rohr & .78 & .73 & .86 & .63 \\
\hline Newquist & .82 & .73 & .92 & .70 \\
\hline Nuzum & .70 & .57 & .82 & .60 \\
\hline Watson & .55 & .54 & .79 & .45 \\
\hline Crawford & .64 & .56 & .73 & .38 \\
\hline Bragg & .87 & .69 & .86 & .65 \\
\hline Miller & .67 & .70 & .77 & .60 \\
\hline Koplan & .75 & .80 & .71 & .71 \\
\hline Askey & .50 & .20 & .63 & .29 \\
\hline Hillman & .75 & .60 & .70 & .53 \\
\hline Mean & .70 & .58 & .77 & .54 \\
\hline$S$ & .11 & .19 & .09 & .15 \\
\hline Coefficient of variation & .16 & .33 & .11 & .27 \\
\hline Range & .37 & .60 & .29 & .42 \\
\hline
\end{tabular}

Source: Author's calculations. 
The data in Table I validate the expected variability in votes by ITC commissioners. They suggest the exercise of discretion in votes on $\mathrm{AD}$ and CVD cases. Is this exercise of discretion related to certain political, professional or employment characteristics?

The results of statistical analysis using two-sample $t$-tests and exact Wilcoxon rank sum tests are shown in Appendix III. Table II summarizes the significant variations in votes by Commissioner attribute. As can be readily seen, significant variation occurs only for two attributes: political party and previous employment in business and labor organizations. Republicans and Democrats differ significantly $(<.05)$ in the results for both the exact Wilcoxon rank sum test and two-sample $t$-test on final CVD votes and on final $\mathrm{AD}$ votes. The votes of commissioners with backgrounds in business and labor differ significantly $(<.05)$ from those who do not have this experience in both the exact Wilcoxon rank sum test and two-sample $t$-test on preliminary CVD votes, final CVD votes, and final AD votes, (and almost significantly in the two-sample $t$-test on preliminary antidumping votes at .058). There is no significant variation found in any votes based on appointing president, or previous employment as

Table II

Summary of Significant Differences (Significant @ .05)

\begin{tabular}{lll}
\hline \multicolumn{1}{c}{$\begin{array}{c}\text { Commissioner } \\
\text { Attribute }\end{array}$} & \multicolumn{1}{c}{$\begin{array}{c}\text { Two Sample } \\
t \text {-Test }\end{array}$} & $\begin{array}{l}\text { Wilcoxon Exact } \\
\text { Rank Sum Test }\end{array}$ \\
\hline Party & CVD fnal & CVD final \\
& AD final & AD final \\
Appointing president & None & None \\
Lawyers & None & None \\
Business and labor & CVD preliminary & CVD preliminary \\
& CVD final & CVD final \\
Congressional staff & AD final & AD final \\
\hline
\end{tabular}

Source: Author's calculations. 
Table III

Antidumping Votes and Political Party of Commissioner (Average Vote Percentages (S.D.))

\begin{tabular}{lllllll}
\hline & & \multicolumn{2}{c}{ CVD Cases } & & \multicolumn{2}{c}{ Antidumping Cases } \\
\cline { 3 - 4 } Commissioners & $n$ & Preliminary & Final & & Preliminary & Final \\
\hline Republican & 5 & $.65(.15)$ & $.45(.21)$ & & $.75(.09)$ & $.42(.14)$ \\
Democrat & 6 & $.74(.05)$ & $.69(.09)$ & & $.80(.09)$ & $.63(.07)$ \\
\hline
\end{tabular}

Source: Author's calculations.

lawyers or on congressional staffs. The results for both the $t$-test and Wilcoxon test lead to identical conclusions.

\section{DISCUSSION}

\section{Political Party}

Moore $^{24}$ found partisan differences in his analysis of 19801986 Commission votes. In his analysis, six of seven Republicans had higher affirmative votes than the three Democratic members. In this analysis, for the period 1992-1999, the pattern is reversed. As shown in Table III, the average affirmative vote rating for Democrats is higher than that of the Republicans. The direction is inconsistent with Moore's observation: four of five Republicans had lower affirmative vote ratings than all six Democrats.

Applying the statistical tests to the data for party affiliation, significant differences by political party are found. Republican commissioners voted differently than Democratic commissioners on final countervailing duty and final antidumping votes. Thus, there is some evidence of party cleavage and there is some support for the hypothesis that party and voting are related. However, this remains a difficult area to explain. On the one

\footnotetext{
${ }^{24}$ Michael O. Moore, "Rules or Politics? An Empirical Analysis of ITC Antidumping Decisions," Economic Inquiry, vol. 30 (July, 1992): 464.
} 
Table IV

Antidumping Votes and Party of Appointing President (Average Vote Percentages (S.D.))

\begin{tabular}{llllllc}
\hline & & \multicolumn{2}{c}{ CVD Cases } & & \multicolumn{2}{c}{ Antidumping Cases } \\
Commissioners & $n$ & Preliminary & Final & & Preliminary & Final \\
\hline Republican & 6 & $.70(.10)$ & $.56(.18)$ & & $.81(.07)$ & $.52(.14)$ \\
Democrat & 5 & $.71(.14)$ & $.60(.23)$ & & $.73(.09)$ & $.56(.16)$ \\
\hline
\end{tabular}

Source: Author's calculations.

hand, this and previous studies have founds some relationship between political party and voting behavior. On the other hand, the direction of vote cleavage is inconsistent. Perhaps, political party is confounded by other variables, or perhaps the direction of party cleavage varies over time as policy direction is influenced either by dominant presidents or dominant Congresses.

\section{Appointing President}

What then about the appointing president? Do votes on the ITC relate to the party of the appointing president? One might expect that presidents seek to influence votes through the appointment of commissioners with views on trade policy that are compatible with the Administration. The average voting data by party of appointing president is shown in Table IV.

Moore's data ${ }^{25}$ show that of nine commissioners appointed by Republican presidents, seven ranked as the highest supporters of protection (affirmative vote range from 1.00 to .65) and two were the lowest (.43 and .22). Three appointed by a Democratic president supported protection at slightly lesser rates $(.71, .63$. and .52). However, votes in the 1992-1999 period show no such discernible pattern. Commissioners appointed by a Democratic president ranked first, third, fifth, seventh, and eleventh in

${ }^{25}$ Ibid. 
affirmative vote percentages. Those appointed by a Republican ranked second, fourth, fifth (tie), eighth, ninth, and tenth.

Applying our statistical tests to the data on appointing presidents indicates no significant difference between the votes of commissioners appointed by Republican presidents and those appointed by a Democratic president. Thus, it cannot be concluded from this analysis that voting behavior on the ITC is related to the party of the appointing president. This is a rather unexpected outcome. It suggests that 1992-1999 may have been a period of Congressional dominance of the appointment process. Alternatively, it may be that the presumed policy preferences of the Democratic and Republican Administrations during this period were not as clearly different as might be assumed; or at least they were not manifested in appointments to the ITC.

\section{Lawyers}

Do lawyers on the ITC vote differently from non-lawyers? It could be argued that lawyers might take a different, more statutebased approach to their decisions. The average voting data for lawyers are shown in Table $\mathrm{V}$.

Applying our statistical tests to this data indicates that there are no significant differences between the votes of lawyers and non-lawyers on the Commission on any of the countervailing

Table $\mathrm{V}$

Lawyers (Average Vote Percentages (S.D.))

\begin{tabular}{lcccccc}
\hline & & \multicolumn{2}{c}{ CVD Cases } & & \multicolumn{2}{c}{ Antidumping Cases } \\
Commissioners & $n$ & Preliminary & Final & & Preliminary & Final \\
\hline Lawyers & 6 & $.70(.10)$ & $.66(.10)$ & & $.77(.08)$ & $.56(.13)$ \\
Non-Lawyers & 5 & $.71(.14)$ & $.49(.25)$ & & $.78(.10)$ & $.50(.17)$ \\
\hline
\end{tabular}

Source: Author's calculations. 
duty or antidumping votes. Therefore it cannot be concluded from this analysis that lawyers vote differently from non-lawyers on the ITC. A legal background thus does not suggest itself as a proxy for statutory-based decision-making on the ITC.

\section{Business and Labor}

Do commissioners with prior employment in business and labor vote differently from those without such experiences? As seen in Table VI Commissioners with backgrounds in business and labor appear to have voted more affirmatively than did their other colleagues.

Applying our statistical tests indicates that significant differences exist on preliminary and countervailing duty and final antidumping votes. Commissioners with previous employment in business or labor voted differently than commissioners without previous experience in business and labor organizations. Perhaps because of their backgrounds in business or labor organizations these commissioners are more personally or ideologically sympathetic toward business and labor petitioners.

\section{Congressional Staff}

Table VII shows the average vote comparisons for commissioners with and without experience as congressional staff

Table VI

Business and Labor (Average Vote Percentages (S.D.))

\begin{tabular}{lllllll}
\hline & & \multicolumn{2}{c}{ CVD Cases } & & \multicolumn{2}{c}{ Antidumping Cases } \\
\cline { 3 - 4 } \multicolumn{1}{c}{ Commissioners } & $n$ & Preliminary & Final & & Preliminary & Final \\
\hline Business and labor & 4 & $.81(.05)$ & $.73(.05)$ & & $.84(.09)$ & $.67(.04)$ \\
Non-business and labor & 7 & $.64(.09)$ & $.49(.19)$ & & $.74(.06)$ & $.46(.12)$ \\
\hline
\end{tabular}

Source: Author's calculations. 
Table VII

Congressional Staff (Average Vote Percentages (S.D.))

\begin{tabular}{lllllll}
\hline & & \multicolumn{2}{c}{ CVD Cases } & & \multicolumn{2}{c}{ Antidumping Cases } \\
\cline { 3 - 4 } \multicolumn{1}{c}{ Commissioners } & $n$ & Preliminary & Final & & Preliminary & Final \\
\hline Congressional staff & 6 & $.72(.05)$ & $.66(.10)$ & & $.77(.06)$ & $.58(.11)$ \\
Non-congressional staff & 5 & $.69(.16)$ & $.48(.25)$ & & $.79(.11)$ & $.49(.18)$ \\
\hline
\end{tabular}

Source: Author's calculations.

members. Former congressional staff members appear to have slightly higher affirmative vote ratings in all categories except preliminary antidumping determinations.

However, applying our statistical tests to the data indicates that no significant differences exist on any of the four vote categories. Thus, former Congressional staff members did not vote differently from those commissioners who had not previously served on Capitol Hill staffs. While it is certainly possible, even highly likely, that interested Senators and representatives may wish to see their former staff members as commissioners on the ITC, their individual policy preferences may differ, and these differences may then be reflected in the policy preferences of former staffers turned commissioners. Thus, while Congressional dominance theory may in fact be at work in the number of appointees who come from Capitol Hill, this analysis does not support the suggestion that former congressional staff members cast votes differently from commissioners who have not worked on Capitol Hill.

Having completed the above analysis, it may be tempting to analyze the data further. Logit/probit analysis, for instance, would provide information about the relative strength of the attributes, and multinomial logit analysis would offer comparisons between votes. However interesting this might be from an analytic perspective, even if given a larger sample size to permit 
such statistical analysis, these results do not indicate great potential for further understanding of voting discretion on the ITC. Instead, more work is needed to identify other alternative hypotheses for which the voting data can be subject to additional analysis.

\section{CONCLUSION}

There is significant variability in votes on antidumping and countervailing duty cases cast by commissioners of the International Trade Commission. Previous studies have suggested that the apparent exercise of discretion by individual commissioners can be explained by certain attributes of commissioners. This study examined the votes of commissioners between 1992 and 1999 to determine if relationships appeared to exist between votes and political party, the party of the appointing president, whether the commissioners were lawyers, and whether they had previous employment in business and labor or on Capitol Hill. There is an indication of a relationship between the vote of ITC Commissioners and prior employment in business and labor and also with political party. In other cases there was no significant relationship. Overall, this simple biographical information is insufficient as a full explanation of the votes of ITC commissioners.

Yet, the persistent variability in voting behavior challenges observers to find explanations. This analysis rejects the more superficial explanations and, in doing so, suggests that explaining and predicting ITC voting behavior requires examination of more subtle and sophisticated factors. The apparent relationships of votes to prior association with business and labor organizations and political party are suggestive in this regard. Matters of personal experience, political ideology, and sources of political support are difficult to determine, quantify, and analyze, but they may provide the next level of analysis necessary to find exogenous 
explanations for ITC voting behavior. One promising area of further inquiry is suggested by the findings of Drope and Hansen of a "... significant positive relationship between petitioners' political activities and affirmative decisions on antidumping cases." 26

Efforts by interested parties to influence the appointment of sympathetic commissioners could also prove instructive. An examination of petitioners' political activity, exercised within the context of principal-agent theory and congressional dominance theory, could address the matter of appointments to the ITC and the votes of commissioners. ${ }^{27}$ In the absence of simple explanations, it might also be time to go directly to present and former commissioner and staff, to elicit explanations about what leads commissioners to interpret economic data differently, select different decision criteria, and exercise voter discretion.

\section{ACKNOWLEDGMENT}

The author gratefully acknowledges the assistance of Kathryn Kocher, of the Naval Postgraduate School, for her assistance conducting the statistical analyses presented in this article.

\section{REFERENCES}

Anderson, K. B. 1993. Agency Discretion or Statutory Direction: Decision Making at the U. S. International Trade Commission. Journal of Law and Economics 36:915-935.

Baldwin, R. E. 1985. The Political Economy of U. S. Import Policy. Cambridge, MA: MIT Press.

\footnotetext{
${ }^{26}$ Jeffrey M. Drope and Wendy Hansen, "Purchasing Protection? The Effect of Political Spending on U.S. Trade Policy," Political Research Quarterly, vol. 57 no. 1 (March 2004): 32.

${ }^{27}$ See James M. DeVault, Congressional Dominance and the International Trade Commission," Public Choice, vol. 110 (2002): 1-22.
} 
Baldwin, R. E., and Steagall, J. W. 1994. An Analysis of ITC Decisions in Antidumping, Countervailing Duty and Safeguard Cases. Weltwirtschaftliches Archives 130:290-308.

Baldwin, R. E., and Moore, M. O. 1991. Political Aspects of the Administration of the Trade Remedy Laws. In: Boltuck, R., and Litan, R. E. (eds.), Down in the Dumps: Administration of the Unfair Trade Laws, pp. 253-280. Washington, DC: Brookings Institution.

Blonigan, B. A., and Brown, C. P. 2003. Antidumping and Retaliation Threats. Journal of International Economics 60:249-273.

Blonigan, B. A., and Prusa, T. J. 2001. Antidumping. NBER Working Paper Series. Cambridge, MA: National Bureau of Economic Research.

Boltuck, R., and Litan, R. E. (eds.). 1991. Down in the Dumps: Administration of the Unfair Trade Laws. Washington, DC: Brookings Institution.

Brook, D. A. 2003. Trade Policy Strategies and Enforcement Choices: An Examination of the 1992 Steel Antidumping Cases. International Trade Journal 17(1):81-99.

Brook, D. A. 2005. Meta-Strategic Lobbying. Business and Politics 7(1):Article 4. [http://www.bepress.com/bap/vol7/ iss1/art4].

DeVault, J. M. 2002. Congressional Dominance and the International Trade Commission. Public Choice 110:1-22.

DeVault, J. M. 1993. Economics and the International Trade Commission. Southern Economic Journal 60:463-478.

Drope, J. M., and Hansen, W. 2004. Purchasing Protection? The Effect of Political Spending on U.S. Trade Policy. Political Research Quarterly 57(1):27-37.

Hansen, W. L. 1990. The International Trade Commission and the Politics of Protectionism. The American Political Science Review 84(1):21-46. 
Hansen, W. L., and Prusa, T. J. 1997. The Economics and Politics of Trade Policy: An Empirical Analysis of ITC Decision Making. Review of International Economics 5:230245.

Kaplan, S. 1991. Injury and Causation in USITC Antidumping Determinations: Five Recent Approaches. In Tharakan, P. K. M. (ed.), Policy Implications of Antidumping Measures, pp. 143-173. Amsterdam: North Holland.

Liebman, B. H. 2001. ITC Voting Behavior on Sunset Reviews. University of Oregon Department of Economics Working Paper.

Moore, M. O. 1992. Rules or Politics? An Empirical Analysis of ITC Antidumping Decisions. Economic Inquiry 30:449-466.

Sabray, F. 2000. An Analysis of the Decision to File, The Dumping Estimates, and the Outcome of Antidumping Petitions. The International Trade Journal 14(2):109-145.

U. S. Congress, Senate, Committee on Finance. March 12, 1984. Hearing: Nominations of Fred T. Goldberg, Jr., Julian I. Jacobs, Alfred H. Kingon, Stephanie Lee-Miller, David C. Mulford, and David B. Rohr. Washington: GPO.

U. S. Congress, Senate, Committee on Finance. July 24, 1985. Hearing: Nomination of Anne E. Brunsdale. Washington: GPO.

U. S. Congress, Senate, Committee on Finance. August 4, 1988. Hearing: Nominations of Don E. Newquist, Ronald A. Cass, and Salvatore R. Martoche. Washington: GPO.

U. S. Congress, Senate, Committee on Finance. June 27, 1991. Hearing: Nominations of Desiree Tucker-Sorini, Janet A. Nuzum, and Carol T. Crawford. Washington: GPO.

U. S. Congress, Senate, Committee on Finance. November 20, 1992. Hearing: Nominations of Alan M. Dunn, Peter S. Watson, and Arnold R. Tompkins. Washington: GPO. 
U. S. Congress, Senate, Committee on Finance. March 16, 1994. Hearing: Nominations of W. Booth Gardner and Lynn M. Bragg. Washington: GPO.

U. S. Congress, Senate, Committee on Finance. June 13, 1996. Hearing: Nominations of Raymond W. Kelly and Marcia E. Miller. Washington: GPO.

U. S. Congress, Senate, Committee on Finance. November 16, 1999. Hearing: Nomination of Deanna T. Okun. Washington: GPO.

\section{APPENDIX I}

Preliminary Antidumping Votes, 1992-1999 ${ }^{\mathrm{A}}$

\begin{tabular}{lccccccccc}
\hline & \multicolumn{8}{c}{ Affirmative/Negative } \\
\cline { 2 - 10 } Commissioner & 1992 & 1993 & 1994 & 1995 & 1996 & 1997 & 1998 & 1999 & Total \\
\hline Brunsdale & $19 / 9$ & $15 / 3$ & $9 / 4$ & & & & & & $43 / 16$ \\
Rohr & $22 / 4$ & $15 / 1$ & $26 / 3$ & $8 / 5$ & $9 / 0$ & & & & $80 / 13$ \\
Newquist & $22 / 1$ & $15 / 0$ & $25 / 3$ & $10 / 3$ & $11 / 0$ & $7 / 1$ & & & $90 / 8$ \\
Nuzum & $13 / 4$ & $15 / 1$ & $24 / 5$ & $8 / 5$ & $9 / 1$ & $4 / 0$ & & & $73 / 16$ \\
Watson & $10 / 4$ & $15 / 2$ & $24 / 4$ & $7 / 6$ & $8 / 1$ & $1 / 0$ & & $65 / 17$ \\
Crawford & $10 / 6$ & $15 / 3$ & $22 / 7$ & $6 / 7$ & $9 / 1$ & $8 / 2$ & $6 / 2$ & $14 / 5$ & $90 / 33$ \\
Bragg & & & $8 / 0$ & $8 / 5$ & $11 / 0$ & $8 / 1$ & $7 / 0$ & $13 / 4$ & $55 / 9$ \\
Miller & & & & & $1 / 0$ & $7 / 1$ & $6 / 1$ & $13 / 6$ & $27 / 8$ \\
Koplan & & & & & & & & $15 / 6$ & $15 / 6$ \\
Askey & & & & & & & & $12 / 7$ & $12 / 7$ \\
Hillman & & & & & & & & $14 / 6$ & $14 / 6$ \\
\hline
\end{tabular}

A Note: The total preliminary and final vote counts do not equal each other or exactly the number of cases. In some instances, commissioners partition cases and cast multiple votes on separate elements of a single case. Also, a time span sometimes approaching one year can intervene between preliminary and final votes, with Commissioners arriving or leaving office in the interim.

Source: Author's calculations from data contained in ITC Annual Reports. 
Final Antidumping Votes, 1992-1999

\begin{tabular}{lccccccccc}
\hline & \multicolumn{8}{c}{ Affirmative/Negative } \\
\cline { 2 - 10 } Commissioner & 1992 & 1993 & 1994 & 1995 & 1996 & 1997 & 1998 & 1999 & Total \\
\hline Brunsdale & $6 / 11$ & $11 / 20$ & $2 / 5$ & & & & & & $19 / 36$ \\
Rohr & $10 / 7$ & $19 / 12$ & $10 / 7$ & $20 / 7$ & $3 / 4$ & & & & $62 / 37$ \\
Newquist & $11 / 5$ & $20 / 10$ & $12 / 4$ & $19 / 8$ & $7 / 2$ & $7 / 4$ & $3 / 0$ & & $79 / 33$ \\
Nuzum & $9 / 2$ & $18 / 14$ & $10 / 7$ & $16 / 11$ & $4 / 4$ & $1 / 0$ & & & $58 / 38$ \\
Watson & $5 / 5$ & $14 / 18$ & $7 / 9$ & $14 / 13$ & $2 / 6$ & $0 / 1$ & & & $42 / 52$ \\
Crawford & $4 / 7$ & $6 / 20$ & $7 / 10$ & $12 / 14$ & $4 / 4$ & $2 / 6$ & $2 / 6$ & $8 / 7$ & $45 / 74$ \\
Bragg & & & $1 / 1$ & $16 / 12$ & $6 / 2$ & $7 / 4$ & $7 / 2$ & $9 / 4$ & $46 / 25$ \\
Miller & & & & & & $7 / 3$ & $5 / 4$ & $8 / 6$ & $20 / 13$ \\
Koplan & & & & & & & $1 / 1$ & $9 / 4$ & $10 / 4$ \\
Askey & & & & & & & $0 / 1$ & $5 / 11$ & $5 / 12$ \\
Hillman & & & & & & & $7 / 6$ & $7 / 6$ \\
\hline
\end{tabular}

Source: Author's calculations from data contained in ITC Annual Reports.

Preliminary Countervailing Duty Votes, 1992-1999

\begin{tabular}{|c|c|c|c|c|c|c|c|c|c|}
\hline \multirow[b]{2}{*}{ Commissioner } & \multicolumn{9}{|c|}{ Affirmative/Negative } \\
\hline & 1992 & 1993 & 1994 & 1995 & 1996 & 1997 & 1998 & 1999 & Total \\
\hline Brunsdale & $4 / 1$ & & $1 / 1$ & & & & & & $5 / 2$ \\
\hline Rohr & $5 / 0$ & & $4 / 2$ & $1 / 1$ & $1 / 0$ & & & & $11 / 3$ \\
\hline Newquist & $5 / 0$ & & $3 / 1$ & $1 / 1$ & $1 / 0$ & & & & $10 / 2$ \\
\hline Nuzum & $2 / 0$ & & $4 / 1$ & $1 / 1$ & $0 / 1$ & & & & $7 / 3$ \\
\hline Watson & $2 / 0$ & & $2 / 2$ & $1 / 1$ & $0 / 1$ & & & & $5 / 4$ \\
\hline Crawford & $1 / 0$ & & $3 / 2$ & $1 / 1$ & $1 / 0$ & & & & $5 / 4$ \\
\hline Bragg & & & $2 / 0$ & $1 / 1$ & $1 / 0$ & & $4 / 0$ & $6 / 1$ & $14 / 2$ \\
\hline Miller & & & & & & & $3 / 1$ & $5 / 3$ & $8 / 4$ \\
\hline Koplan & & & & & & & & $6 / 2$ & $6 / 2$ \\
\hline Askey & & & & & & & & $4 / 4$ & $4 / 4$ \\
\hline Hillman & & & & & & & & $6 / 2$ & $6 / 2$ \\
\hline
\end{tabular}

Source: Author's calculations from data contained in ITC Annual Reports. 
Final Countervailing Duty Votes, 1992-1999

\begin{tabular}{lccccccccc}
\hline & \multicolumn{7}{c}{ Affirmative/Negative } \\
\cline { 2 - 10 } Commissioner & 1992 & 1993 & 1994 & 1995 & 1996 & 1997 & 1998 & 1999 & Total \\
\hline Brunsdale & $1 / 3$ & $1 / 2$ & $0 / 1$ & & & & & & $2 / 6$ \\
Rohr & $1 / 1$ & $3 / 0$ & $4 / 0$ & $2 / 3$ & $1 / 0$ & & & & $11 / 4$ \\
Newquist & $1 / 1$ & $3 / 0$ & $4 / 0$ & $3 / 3$ & $1 / 0$ & $2 / 0$ & $0 / 1$ & & $14 / 5$ \\
Nuzum & $1 / 1$ & $3 / 0$ & $2 / 2$ & $1 / 3$ & $1 / 0$ & & & & $8 / 6$ \\
Watson & $1 / 0$ & $2 / 1$ & $2 / 1$ & $1 / 3$ & $0 / 1$ & & & & $6 / 5$ \\
Crawford & $1 / 0$ & $1 / 2$ & $3 / 1$ & $1 / 3$ & $1 / 0$ & $3 / 1$ & $1 / 2$ & $3 / 2$ & $14 / 1$ \\
Bragg & & & & $3 / 3$ & $1 / 0$ & $3 / 0$ & $1 / 1$ & $3 / 1$ & $11 / 5$ \\
Miller & & & & & & $3 / 0$ & $1 / 1$ & $3 / 2$ & $7 / 3$ \\
Koplan & & & & & & & $1 / 0$ & $3 / 1$ & $4 / 1$ \\
Askey & & & & & & & $0 / 1$ & $1 / 4$ & $1 / 5$ \\
Hillman & & & & & & & $3 / 2$ & $3 / 2$ \\
\hline
\end{tabular}

Source: Author's calculations from data contained in ITC Annual Reports.

\section{APPENDIX II}

Characteristics of ITC Commissioners, 1992-1999

\begin{tabular}{lccccc}
\hline Commissioner & Party & $\begin{array}{c}\text { Appointing } \\
\text { President }\end{array}$ & Bus/Labor & $\begin{array}{c}\text { Congress } \\
\text { Staff }\end{array}$ & Lawyer \\
\hline Brunsdale & $\mathrm{R}$ & $\mathrm{R}$ & & & \\
Rohr & $\mathrm{D}$ & $\mathrm{R}$ & $\mathrm{x}$ & $\mathrm{x}$ & \\
Newquist & $\mathrm{D}$ & $\mathrm{R}$ & $\mathrm{x}$ & & $\mathrm{x}$ \\
Nuzum & $\mathrm{D}$ & $\mathrm{R}$ & & $\mathrm{x}$ & \\
Watson & $\mathrm{R}$ & $\mathrm{R}$ & & & $\mathrm{x}$ \\
Crawford & $\mathrm{R}$ & $\mathrm{R}$ & & $\mathrm{x}$ & $\mathrm{x}$ \\
Bragg & $\mathrm{R}$ & $\mathrm{D}$ & $\mathrm{x}$ & & \\
Miller & $\mathrm{D}$ & $\mathrm{D}$ & & $\mathrm{x}$ & $\mathrm{x}$ \\
Koplan & $\mathrm{D}$ & $\mathrm{D}$ & $\mathrm{x}$ & $\mathrm{x}$ & $\mathrm{x}$ \\
Askey & $\mathrm{R}$ & $\mathrm{D}$ & & & \\
Hillman & $\mathrm{D}$ & $\mathrm{D}$ & & $\mathrm{x}$ & $\mathrm{x}$ \\
\hline
\end{tabular}

Source: Author, from information in ITC Annual Reports. 


\section{APPENDIX III}

\begin{tabular}{|c|c|c|c|c|}
\hline \multirow{2}{*}{$\begin{array}{c}\text { Commissioner } \\
\text { Attributes }\end{array}$} & \multicolumn{2}{|c|}{ CVD Cases } & \multicolumn{2}{|c|}{ Antidumping Cases } \\
\hline & Preliminary & Final & Preliminary & Final \\
\hline Party & .227 & .017 & .576 & .045 \\
\hline Appointing president & .894 & .623 & .141 & .697 \\
\hline Lawyers & .755 & .355 & .703 & .567 \\
\hline Business and labor & .009 & .012 & .097 & .006 \\
\hline Congressional staff & .999 & .193 & .617 & .507 \\
\hline
\end{tabular}

Two-Sample $t$-Test Results $(\operatorname{Pr}>|t|)$

\begin{tabular}{lccccc}
\hline \multirow{2}{*}{$\begin{array}{c}\text { Commissioner } \\
\text { Attributes }\end{array}$} & \multicolumn{2}{c}{ CVD Cases } & & \multicolumn{2}{c}{ Antidumping Cases } \\
\cline { 2 - 3 } & Preliminary & Final & & Preliminary & Final \\
\hline Party & .186 & .031 & & .373 & .011 \\
Appointing president & .912 & .785 & & .159 & .693 \\
Lawyers & .832 & .165 & & .858 & .544 \\
Business and labor & .011 & .031 & & .058 & .009 \\
Congressional staff & .729 & .135 & & .706 & .352 \\
\hline
\end{tabular}


Copyright of International Trade Journal is the property of Routledge, Ltd.. The copyright in an individual article may be maintained by the author in certain cases. Content may not be copied or emailed to multiple sites or posted to a listserv without the copyright holder's express written permission. However, users may print, download, or email articles for individual use. 